\title{
Hyperthyroidism and Developmental Dysfunction
}

\author{
Ahmed RG* \\ Division of Anatomy and Embryology, Zoology Department, Faculty of Science, Beni-Suef University, Beni-Suef, Egypt
}

*Corresponding author: Ahmed RG, Division of Anatomy and Embryology, Zoology Department, Faculty of Science, Beni-Suef University, Beni-Suef, Egypt, Tel: 002-010-91471828; E-mail: ahmedragab08@gmail.com

Received date: July 24, 2017; Accepted date: August 04, 2017; Published date: August 07, 2017

Citation: Ahmed RG. Hyperthyroidism and Developmental Dysfunction. Arch Med. 2017, 9:4

Copyright: (c) 2017 Ahmed RG. This is an open-access article distributed under the terms of the Creative Commons Attribution License, which permits unrestricted use, distribution, and reproduction in any medium, provided the original author and source are credited.

\section{Letter to Editor}

Thyroid hormones (THs) are essential for normal growth and development [1-30]. Hyperthyroidism causes a thyrotoxicosis [31], membrane lipid alterations [32], TSH reduction [4], neuropsychiatric and neurologic syndromes and myopathy $[4,33]$. In neonatal hyperthyroidism, cardiac symptoms, and abnormal neurological behaviors were observed by several authors [4,34-37]. Fetal thyrotoxicosis is the result of thyroidstimulating antibody transfer to the fetus in the setting of maternal Grave's disease [6,38]. A fetal hydrops, demise, intrauterine growth restriction, and goiter were reported by Zimmerman et al. [39] and Ahmed et al. [4]. In maternal hyperthyroidism, the placenta lacks to optimize the maternaofetal transfer of THs [6].

My group reported the following (1) The hyperthyroid rat newborns showed larger and less thyroid follicles with flattened cell lining epithelium, decreased thyroid gland size, hyperemic blood vessels, dispersing oedema and degenerative changes along the first 4 postnatal weeks [27]; (2) The maternofetal thyrotoxicosis by L-thyroxine (L-T4) alters the developing hypothalamic-pituitary-thyroid axis (HPTA), growth hormone (GH)/insulin-like growth factor-1 (IGF1) and cytokines/ adipokines axes [10-12]; (3) Maternal hyperthyroidism disturbs the levels of iodothyronine 5'-monodeiodinase (5'-DI), monoamines [norepinephrine (NE), epinephrine (E), dopamine (DA) and serotonin (5-HT)], $\gamma$-aminobutyric acid (GABA), acetylcholinesterase (AchE), and ATPase-enzymes ( $\mathrm{Na}+\mathrm{K}+-$ ATPase, Ca2+-ATPase and Mg2+-ATPase) in brain of neonatal rats [1]; (4) Hyperthyroidism disrupts the neurogenesis, interneuronal connections, neuronal integration and functional alterations [4] and this may be attributed to prooxidant and antioxidant disorders [6,7]; (5) Maternal hyperthyroidism degenerates the pyramidal and polymorphic cells was noted with loss of the axons or lateral dendrites of pyramidal cells [1]; (6) Maternal hyperthyroidism degenerates the stellate, basket, Purkinje, Golgi and granule cells of neonatal cerebellum [4]; and (7) Maternal hyperthyroidism increases the growth of neonatal skeletal system [27]. Thus, the administrations of L-T4 to mothers may cause several injurious anomalies in the development of their newborns and may lead to a pathophysiological state [6]. Age may represent a factor determining the severity and reversibility of the effects of hyper functioning of thyroid gland in the growth of various rat organs. These findings fit well with our previous review [4]. However, whether the adverse effects of maternal hyperthyroidism on fetal development are mediated directly by loss of the maternal hormones contribution to the fetus, indirectly by metabolic impairment of gestation, or both. Further studies need to be done to emphasize this concept. Collectively, my work recommended that the importance of maintaining normal maternal thyroid functions during pregnancy or lactation periods is required to prevent the appearance of any embryonic or fetal disorders.

\section{Conflict of Interest}

The author declares that no competing financial interests exist.

\section{References}

1. Ahmed OM, Abd El-Tawab SM, Ahmed RG (2010) Effects of experimentally induced maternal hypothyroidism and hyperthyroidism on the development of rat offspring: I- The development of the thyroid hormones-neurotransmitters and adenosinergic system interactions. Int J Dev Neurosci 28: 437-454.

2. Ahmed OM, Ahmed RG (2012) Hypothyroidism. In A New Look At Hypothyroidism. Dr. D. Springer Edn., Tech Open Access Publisher, pp: 1-20.

3. Ahmed OM, Ahmed RG, El-Gareib AW, El-Bakry AM, Abd ElTawaba SM (2012) Effects of experimentally induced maternal hypothyroidism and hyperthyroidism on the development of rat offspring: II-The developmental pattern of neurons in relation to oxidative stress and antioxidant defense system. Int J Dev Neurosci 30: 517-537

4. Ahmed OM, El-Gareib AW, El-bakry AM, Abd El-Tawab SM, Ahmed RG (2008) Thyroid hormones states and brain development interactions. Int J Dev Neurosci 26: 147-209.

5. Ahmed RG (2011) Perinatal 2, 3, 7, 8-tetrachlorodibenzo-p-dioxin exposure alters developmental neuroendocrine system. Food Chem Toxicology 49: 1276-1284.

6. Ahmed RG (2012) Maternal-newborn thyroid dysfunction. In the developmental Neuroendocrinology, LAP LAMBERT Academic Publishing GmbH \& Co KG, Germany, pp: 1-369. 
7. Ahmed RG (2012) Maternal-Fetal Thyroid Interactions, Thyroid Hormone, Dr. N.K. Agrawal Edn., In Tech Open Access Publisher, pp: $125-156$

8. Ahmed RG (2013) Early weaning PCB 95 exposure alters the neonatal endocrine system: thyroid adipokine dysfunction. J Endocrinol 219: 205-215.

9. Ahmed RG (2014) Do PCBs modify the thyroid-adipokine axis during development? Annals Thyroid Res 1: 11-12.

10. Ahmed RG (2015) Chapter 1: Hypothyroidism and brain development. In Advances in Hypothyroidism Treatment. Avid Science Borsigstr, Berlin, Germany, pp: pp. 1-40.

11. Ahmed RG (2015) Hypothyroidism and brain developmental players. Thyroid Research J 8: 1-12.

12. Ahmed RG (2015) Maternofetal thyroid action and brain development. J adv boil 7: 1207-1213.

13. Ahmed RG (2016) Gestational dexamethasone alters fetal neuroendocrine axis. Toxicol Lett 258: 46-54.

14. Ahmed RG (2016) Neonatal polychlorinated biphenyls-induced endocrine dysfunction. Ann Thyroid Res 2: 34-35.

15. Ahmed RG (2016) Maternal iodine deficiency and brain disorders. Endocrinol Metab Syndr 5: 223.

16. Ahmed RG (2016) Maternal bisphenol A alters fetal endocrine system: Thyroid adipokine dysfunction. Food Chem Toxicology 95 : 168-174.

17. Ahmed RG, Abdel-Latif M, Ahmed F (2015) Protective effects of GM-CSF in experimental neonatal hypothyroidism. Int Immunopharmacol 29: 538-543.

18. Ahmed RG, Abdel-Latif M, Mahdi E, El-Nesr K (2015) Immune stimulation improves endocrine and neural fetal outcomes in a model of maternofetal thyrotoxicosis. Int Immunopharmacol 29: 714-721.

19. Ahmed RG, Davis PJ, Davis FB, De Vito P, Farias RN, et al. (2013) Nongenomic actions of thyroid hormones: from basic research to clinical applications. An update. Curr Med Chem Immunol Endocr Metab Agents 13: 46-59.

20. Ahmed RG, El-Gareib AW (2014) Lactating PTU exposure: I- Alters thyroid-neural axis in neonatal cerebellum. Eur $\mathrm{J}$ of Biol and Medical Sci Res 2: 1-16.

21. Ahmed RG, El-Gareib AW (2017) Maternal carbamazepine alters fetal neuroendocrine-cytokines axis. Toxicology 382: 59-66.

22. Ahmed RG, El-Gareib AW, Incerpi S (2014) Lactating PTU exposure: II- Alters thyroid-axis and prooxidant-antioxidant balance in neonatal cerebellum. Int Res J of Natural Sciences 2: 1-20.

23. Ahmed RG, Incerpi S (2013) Gestational doxorubicin alters fetal thyroid-brain axis. Int. J Devl Neuroscience 31: 96-104.

24. Ahmed RG, Incerpi S, Ahmed F, Gaber A (2013) The developmental and physiological interactions between free radicals and antioxidant: Effect of environmental pollutants. J of Natural Sci Res 3: 74-110.
25. Candelotti E, De Vito P, Ahmed RG, Luly P, Davis PJ, et al. (2015) Thyroid hormones crosstalk with growth factors: Old facts and new hypotheses. Immun Endoc \& Metab Agents in Med Chem 15: 71-85.

26. De Vito P, Candelotti E, Ahmed RG, Luly P, Davis PJ, et al. (2015) Role of thyroid hormones in insulin resistance and diabetes. Immun Endoc \& Metab Agents in Med Chem 15: 86-93.

27. El-bakry AM, El-Ghareeb AW, Ahmed RG (2010) Comparative study of the effects of experimentally-induced hypothyroidism and hyperthyroidism in some brain regions in albino rats. Int J Dev Neurosci 28: 371-389.

28. El-Ghareeb AA, El-Bakry AM, Ahmed RG, Gaber A (2016) Effects of zinc supplementation in neonatal hypothyroidism and cerebellar distortion induced by maternal carbimazole. Asian Journal of Applied Sciences 4: 1030-1040.

29. Incerpi S, Hsieh MT, Lin HY, Cheng GY, De Vito P, et al. (2014) Thyroid hormone inhibition in L6 myoblasts of IGF-I-mediated glucose uptake and proliferation: New roles for integrin $\alpha v \beta 3$. Am J Physiol Cell Physiol 307: C150-C161.

30. Van Herck SLJ, Geysens S, Bald E, Chwatko G, Delezie E, et al. (2013) Maternal transfer of methimazole and effects on thyroid hormone availability in embryonic tissues. Endocrinol 218 : 105-115.

31. Wemeau JL (2005) Hyperthyroidism: current concepts and management. Rev Prat 55: 149-157.

32. Ruggiero FM, Landriscrina C, Gnoni GV, Quagliariello E (1984) Lipid composition of liver mitochondria and microsomes in hyperthyroid rats. Lipids 19: 171-178.

33. Sinclair C, Gilchrist JM, Hennessey JV, Kandula M (2005) Muscle carnitine in hypo- and hyperthyroidism. Muscle Nerve 32 357-359.

34. Péter F, Muzsnai A (2011) Congenital disorders of the thyroid: Hypo/hyper. Pediatr Clin North Am 58: 1099-1115.

35. Rugge B, Balshem H, Sehgal R, Relevo R, Gorman P, et al. (2011) Screening and treatment of subclinical hypothyroidism or hyperthyroidism. Agency for Healthcare Research and Quality (US), 11(12)-EHC033-EF.

36. Pearce EN (2012) lodine-induced thyroid dysfunction: Comment on "Association between iodinated contrast media exposure and incident hyperthyroidism and hypothyroidism". Arch Intern Med 172: 159-161.

37. Rhee CM (2012) Association between iodinated contrast media exposure and incident hyperthyroidism and hypothyroidism. Arch Intern Med 172: 153-159.

38. Jaeggi ET, Roman KS (2006) Maternal autoimmune disease and its impact on the fetal heart: management and prognosis. Prog Pediatr Cardiol 22: 85-93.

39. Zimmerman D (1999) Fetal and neonatal hyperthyroidism. Thyroid 9: 727-733. 